From the Department of Reproductive Physiology and Pathology, Norwegian College of Veterinary Medicine, Oslo and the Norwegian Red Cattle Association, Hamar.

\title{
Postpartum Reproductive Performance in Dairy Cows in Relation to Phosphorus Status
}

By E. Ropstad, S. I. Ormsettrø and A. O. Refsdal

\begin{abstract}
Ropstad E., S. I. Ormsettre and A. O. Refsdal: Postpartum reproductive performance in dairy cows in relation to phosphorus status. Acta vet. scand. 1988, 29, 347-356. - The levels of inorganic phosphorus in blood samples from two cow populations were related to reproductive performance. Group I comprised 305 dairy cows from 17 herds with normal fertility. The herds were visited every 2-4 weeks. Blood samples were collected from animals between 4 weeks prior to expected calving and subsequent confirmed pregnancy.

The individual mean plasma phosphorus level in samples collected from 0-90 days after calving in cows which conceived following insemination $(n=262)$ was related to reproductive performance.

Group II comprised cows from 47 herds with reproductive problems. The herds were visited once during the indoor season for blood sampling. Mean herd serum phosphorus levels were related to herd reproductive performance registered during a period from 6 months before to 9 months after the time of blood sampling. Overall mean herd phosphorus levels were $1.51 \pm 0.08 \mathrm{mmol} / 1$ plasma $( \pm \mathrm{SD})$ (Group I) and $1.77 \pm 0.16 \mathrm{mmol} / \mathrm{l}$ serum ( $\pm \mathrm{SD}$ ) (Group II). In Group I (indivudual cows), the coefficient of correlation between phosphorus levels and elapsed time from calving to pregnancy was low $(r=0.10, p<0.1)$. In Group II (herds) significant correlations were observed between the fertility status index (FS), the average number of days from calving to last insemination and phosphorus levels ( $r_{s}=0.32, P<0.05$ and $r_{s} p<0.05$, respectively).

The mean herd phosphorus levels were within normal limits in both groups. Although increased phosphorus levels were associated with lower fertility in both groups, the amount of the total fertility variation which could be explained by phosphorus levels was small.
\end{abstract}

inorganic phosphorus; cattle; fertility.

\section{Introduction}

Most of the phosphorus in the blood is present as organic esters within the erythrocytes. Serum contains about $4.8 \mathrm{mmol}$ phosphorus per liter. About half of this is incorporated in lipids. The most significant fraction of the remainder is present as inorganic phosphorus (Simesen 1980). According to
Simesen (1980), measurement of inorganic phosphorus provides the most readily determinable index of the phosphorus status of the animals.

Phosphorus deficiency has been shown to be related to reduced fertility (Theiler 1933, Svanberg \& Sandstedt 1944, Hignett \& Hignett 1951 and 1952, Morrow 1969). The 
same applies to phosphorus excess (Reisshauer 1971, Hewett 1974, Lotthammer 1974). According to Lotthammer (1982), excess of phosphorus is connected with lowered conception rates, increased frequency of silent oestrus, irregular cycles, and metritis. However, the mechanism by which phosphorus influences fertility is unclear.

The present investigation was undertaken to study possible relationships between phosphorus levels and reproductive performance under Norwegian conditions.

\section{Materials and methods}

\section{Group I}

Seventeen dairy herds of Norwegian Red Cattle from the counties of Akershus and Hedmark were studied for 1 year starting in February 1983. The herds were chosen to represent herds with a close-to-normal fertility. Visits were made for blood sampling every 2-4 weeks, selecting cows in the stage between 4 weeks prior to expected calving and the next confirmed pregnancy. A total of 1842 jugular venous samples were collected from 305 cows by means of heparinized vacutainers. The plasma was separated immediately and stored at $-20^{\circ} \mathrm{C}$ until analyzed for inorganic phosphorus.

The cattle were fed home grown roughage, mainly grass silage, and a standardized concentrate (Kufôr A, $12.5 \%$ protein) was fed as a supplement. In 9 herds, the animals were on pasture during the summer season.

Data concerning stage of lactation, number of lactation and reproductive performance, were obtained from herd recording files. Pregnancy was confirmed by rectal palpation 6 weeks after insemination. When studying the relationship between phosphorus levels and fertility in individual animals, the mean phosphorus values of samples collected from 0-90 days after calving were used. Animals which were slaughtered before a pregnancy diagnosis could be made or for other reasons were not confirmed as being pregnant, were excluded from the final analysis. This was done because very little information was available about these cows. The general impression was, however, that infertility was only one of many other reasons for culling these cows. An end total of 810 samples from 262 animals remained to be related to reproductive parameters.

The following reproductive parameters were registered in individual animals:

$\mathrm{CFI}_{1}$ - Number of days from calving to first insemination

CC - Number of days from calving to conception

$\mathrm{BP}_{\mathrm{I}}$ - Length of the breeding period $\left(\mathrm{BP}_{\mathrm{I}}\right.$ $=\mathrm{CC}-\mathrm{CFI}_{1}$ )

NIC - Number of inseminations per conception.

Herd fertility was recorded as described for Material II from January 1983 until March 1984. Herd fertility was related to the mean phosphorus level of all samples collected in each herd.

\section{Group II}

Forty-seven dairy herds of Norwegian Red Cattle from 14 counties were blood sampled once during the indoor season, from 1982 through 1984 . Herd sizes ranged from 11 to 78 cows (i.e. number of animals inseminated), with an average of 26.1. The herds were selected for the study on the basis of reports from local veterinarians and herd owners concerning problems associated either with frequent returns to service, high incidence of ovarian cysts or anoestrus.

Blood samples were taken from a total of 686 dairy cows; 41 dry cows and 645 lactating cows. The number of samples collected in each herd varied according to herd size. In herds with less than 20 cows all cows were blood sampled. In larger herds, 21 cows we- 
re sampled, comprising 3 groups of 7 with high, medium and low yield (this latter group including dry cows). The blood samples were collected by local veterinarians into vacutainers without anticoagulant added. All samples were collected between 10.00 a.m. and 1.00 p.m. The separation of serum and the analysis for inorganic phosphorus normally took place the day after sample collection.

The mean phosphorus levels of the herds were related to herd reproductive performance. Data on feeding, yield and reproductive parameters were obtained from herd recording files and fertility statistics. The following reproductive parameters were registered during a period from 6 months before, to 9 months after, the time of blood sampling:

I - Number of animals inseminated

$\mathrm{CFI}_{\mathrm{II}}$ - Average number of days from calving to first insemination

CLI - Average number of days from calving to last insemination

$\mathrm{BP}_{11}$ - Average length of the breeding pe$\operatorname{riod}\left(\mathrm{BP}_{11}=\mathrm{CLI}-\mathrm{CFI}_{11}\right)$

NIA - Average number of inseminations pr. animal inseminated

RRO-3 - Return rate 0-3 days after insemination

NR60 - Non-return rate 60 days after insemination

AC - Number of animals culled due to infertility

FS - Fertility status index expressed by the formula:

$\mathrm{FS}=\frac{\left[\frac{\mathrm{NR} 60+\mathrm{RRO}-3}{\mathrm{NIA}}-(\mathrm{CLI}-125)\right] \times(1-\mathrm{AC})}{\mathrm{I}}$

\section{Analysis of phosphorus}

Plasma and serum inorganic phosphorus was analyzed by a Technicon Auto-Analyzer according to a photometric method based on the reduction of phosphomolybdate with stannous chloride (Technicon method No. SE-4-0004 FH4). Results are expressed as $\mathrm{mmol} / \mathrm{l}$ plasma or serum.

\section{Statistical analysis}

The General Linear Model from Statistical Analysis System (SAS 1985) was used. Correlation analysis (Spearman correlation coefficient, $r_{s}$ ) was used to assess the relationship between phosphorus levels and reproductive parameters. Results from Group I were analyzed by the following model:

Yijk $=\mu+\mathrm{Hi}+\mathrm{Mj}+\mathrm{Lk}+\mathrm{aP}+$ Eijk

where:

Yijk = the ijkth fertility criterion to be studied

$\mu \quad=$ general mean

$\mathrm{Hi}=$ effect of the ith herd $(\mathrm{i}=1 \ldots .17)$

$\mathrm{Mj}=$ effect of the jth calving month $(\mathrm{j}=$ $1 \ldots .12$ )

Lk = effect of the kth number of lactation $(\mathrm{k}=1 \ldots .9)$

$\mathrm{aP} \quad=$ phosphorus level, $\mathrm{mmol} / \mathrm{l}$

Eijk $=$ residual random term

Results from Group II were analyzed by the following model:

Yij $=\mu+\mathrm{Ci}+\mathrm{Mj}+\mathrm{aP}+\mathrm{Eij}$

where:

Yij $=$ the ijth herd fertility criterion to be studied

$\mu \quad=$ general mean

$\mathrm{Ci}=$ effect of the ith $\mathrm{kg}$ concentrates given at 1 st insemination

$\mathrm{Mj} \quad=$ effect of the jth $\mathrm{kg}$ milk produced at 1 st insemination

$\mathrm{aP} \quad=$ phosphorus level, $\mathrm{mmol} / \mathrm{l}$

Eij $=$ residual random term

\section{Results}

In Group I, the fertility was on average close to normal for Norwegian dairy cows (Tables 1 and 2). In Group II, fertility was conside- 
Table 1. Overall herd means \pm SD for inorganic phosphorus and reproductive parameters in Group I and II for the period between $1 / 1 / 83$ and $31 / 3 / 84$. Country means for the same period are included for comparison (data supplied by the Norwegian Red Cattle Association).

\begin{tabular}{lcccc}
\hline \multirow{2}{*}{ Variables!) } & \multicolumn{3}{c}{ Overall herd means \pm SD } & Country \\
\cline { 2 - 4 } & \multicolumn{2}{c}{$\begin{array}{c}\text { Group I } \\
(\mathrm{n}=17)\end{array}$} & $\begin{array}{l}\text { Group II } \\
(\mathrm{n}=47)\end{array}$ & means \\
\hline IP & $1.51 \pm 0.08$ (plasma) & $1.77 \pm 0.16$ (serum) & - \\
CFI $_{\text {II }}$ & $75.8 \pm 17.7$ & $71.3 \pm 12.4$ & 77 \\
CLI & $99.2 \pm 9.6$ & $109.9 \pm 19.4$ & 102 \\
BP $_{\text {II }}$ & $19.9 \pm 6.4$ & $38.6 \pm 17.6$ & 25 \\
NIA & $1.63 \pm 0.20$ & $2.30 \pm 0.76$ & 1.8 \\
NR60 & $66.9 \pm 8.9$ & $47.3 \pm 15.9$ & 60 \\
FS & $68.6 \pm 13.3$ & $42.6 \pm 24.8$ & 60 \\
\hline
\end{tabular}

1) IP = Mean level of inorganic phosphorus $(\mathrm{mmol} / \mathrm{l})$

$\mathrm{CFI}_{\mathrm{II}}=$ Average number of days from calving to first insemination

$\mathrm{CLI}=$ Average number of days from calving to last insemination

$\mathrm{BP}_{\mathrm{II}} \quad=$ Average length of breeding period $\left(\mathrm{BP}_{\mathrm{II}}=\mathrm{CLI}-\mathrm{CFI}_{\mathrm{II}}\right)$

NIA $=$ Average number of inseminations per animal inseminated

NR60 = Non-return rate 60 days after insemination

FS $\quad=$ Fertility status, an integrated index

Table 2. Means \pm SD for inorganic phosphorus and reproductive parameters in 262 animals which conceived after calving (Group I).

\begin{tabular}{lc}
\hline Variables 1$)$ & means \pm SD \\
\hline IP & $1.55 \pm 0.22$ \\
CFI & $80.1 \pm 22.2$ \\
CC & $99.0 \pm 35.4$ \\
BP $_{1}$ & $18.9 \pm 30.5$ \\
NIC & $1.63 \pm 0.97$ \\
\hline
\end{tabular}

1) IP = Inorganic phosphorus in plasma expressed as a mean of samples collected from 0-90 days after calving $\mathrm{mmol} / 1$

$\mathrm{CFI}_{1}=$ Number of days from calving to first insemination

$\mathrm{CC}=$ Number of days from calving to conception

$\mathrm{BP}_{1}=$ Length of the breeding period $\left(\mathrm{BP}_{\mathrm{I}}=\mathrm{CC}-\mathrm{CFI}_{\mathrm{I}}\right)$

NIC $=$ Number of inseminations per conception

rably lower than that which is regarded as normal (Table 1).

The overall mean phosphorus levels of the herds were $1.51 \pm 0.08( \pm \mathrm{SD}) \mathrm{mmol} / \mathrm{l}$ plasma and $1.77 \pm 0.16( \pm \mathrm{SD}) \mathrm{mmol} / \mathrm{l} \mathrm{se}-$ rum for Group I and II, respectively (Table 1). The average phosphorus level among individual animals $(n=262)$ in which phosphorus levels were related to various fertility criteria was $1.55 \pm 0.22( \pm \mathrm{SD}) \mathrm{mmol} / \mathrm{l}$ 


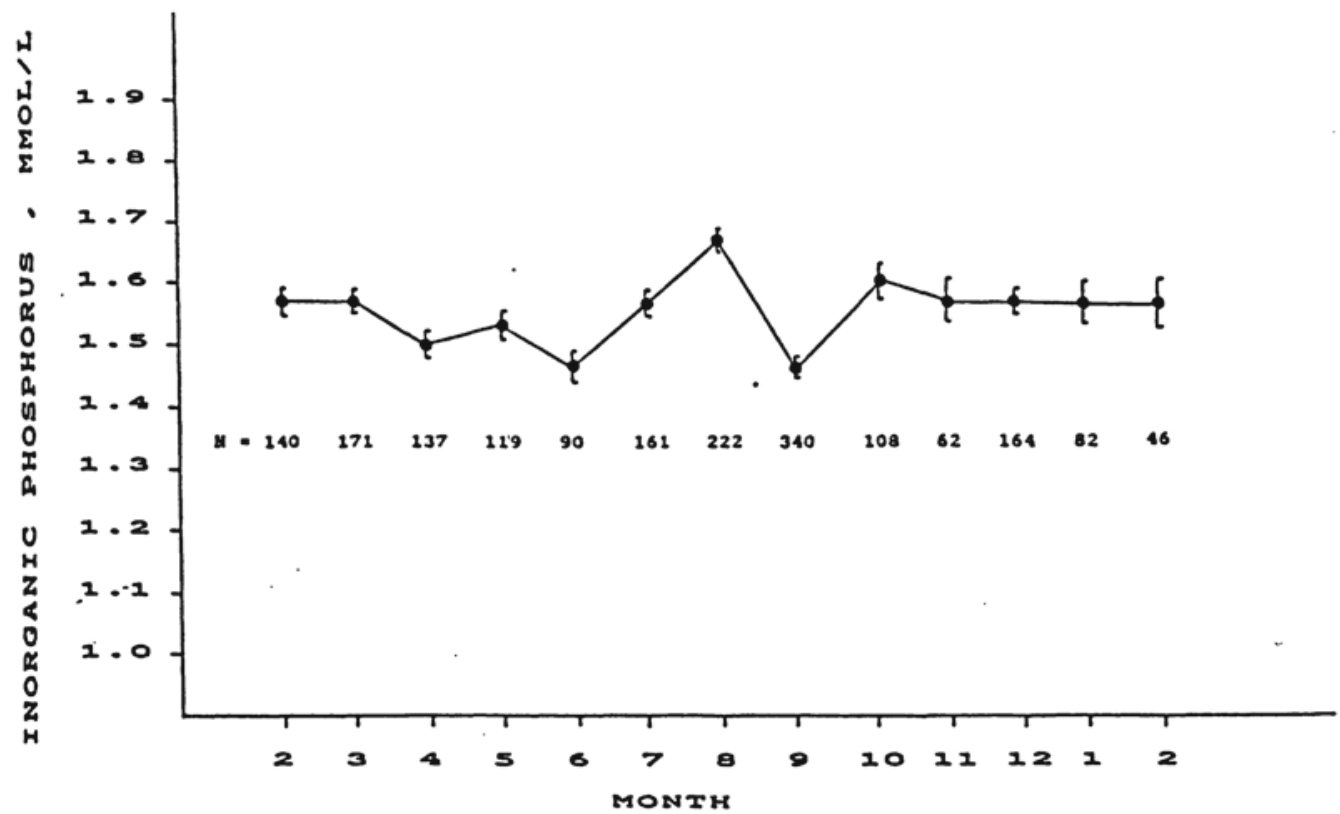

Figure 1. Mean levels of inorganic phosphorus in plasma related to month of sampling in Material I. Vertical bars represent standard errors. A total of 1.842 samples were analyzed $(n=$ number of observations).

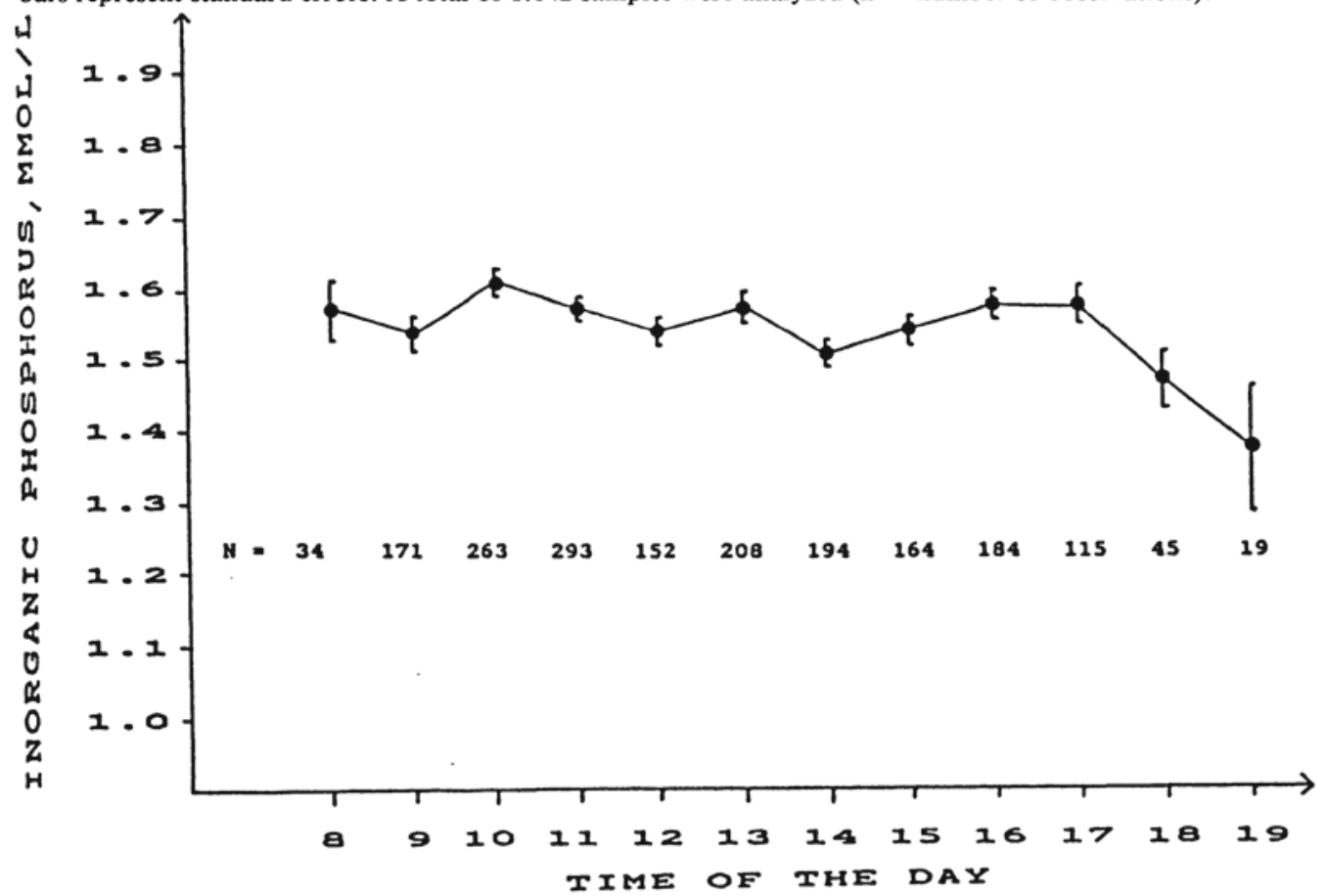

Figure 2. Mean levels of inorganic phosphorus in plasma of samples collected at different times of the day in Material I. Vertical bars represent standard errors. A total of 1.842 samples were analyzed $(n=$ number of observations). 
plasma (Group I) (Table 2). The mean phosphorus levels remained stable during the winter season. Though some variation was observed during the summer season, no consistent pattern was observed (Fig. 1). Only small variations were observed when mean phosphorus levels in Group I were related to the time of sampling during the day (Fig. 2). A tendency of positive correlation was observed between number of days from calving to first insemination $\left(\mathrm{CFI}_{\mathrm{I}}\right)$, number of days from calving to conception (CC) and mean phosphorus levels for individual animals in Group I ( $\mathrm{n}=262, \mathrm{r}_{\mathrm{s}}=0.11, \mathrm{p}<0.10$ and $\mathrm{r}_{\mathrm{s}}$ $=0.10, \mathrm{p}<0.10$, respectively). Herd fertility results in Group I were, however, not significantly correlated with average phosphorus levels of the herds.

In Group II, significant correlations were observed between the fertility status index (FS), average number of days from calving to last insemination (CLI) and the mean

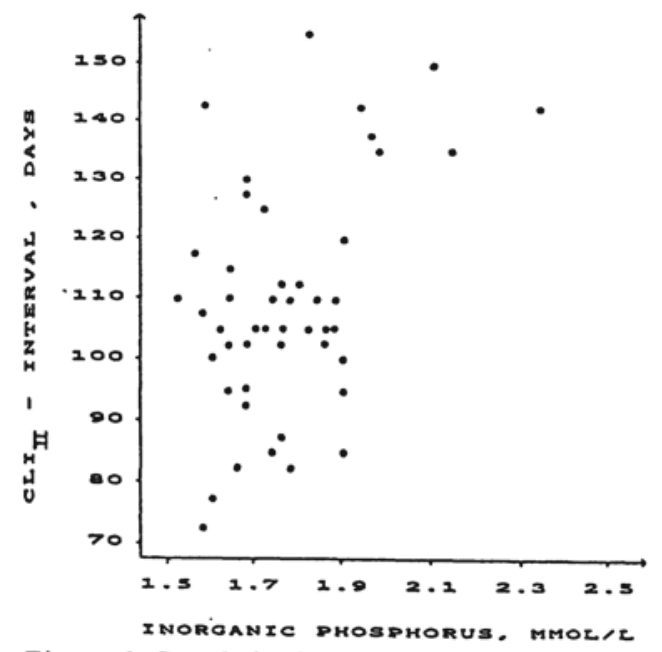

Figure 3. Correlation between mean level of inorganic phosphorus in serum and average number of days from parturition to last insemination in $\mathbf{4 7}$ herds with reproductive problems (Material II).

$\mathrm{y}=54.6 * \mathrm{X}+13.3, \mathrm{r}_{\mathrm{s}}=0.31$ phosphorus levels of the herds $\left(r_{s}=-0.32, p\right.$ $<0.05$ and $\mathrm{r}_{\mathrm{s}}=0.31, \mathrm{p}<0.05$, respectively) (Fig. 3).

Analysis of variance on the Group I data revealed a minor but significant relationship between phosphorus level and the interval from calving to conception (CC). Calving month was significantly related to all fertility criteria studied. The herd factor was significantly related to the number of days from calving to first insemination (Table 3 ). No significant relationship was found between phosphorus levels and length of the breeding period, nor between phosphorus levels and number of inseminations per conception.

In Group II, phosphorus levels explained $18.0 \%(\mathrm{p}<0.001), 15.2 \%(\mathrm{p}<0.01)$ and $14.1 \%(\mathrm{p}<0.01)$ of the variation in the average number of days from calving to last insemination (CLI), the length of the breeding period $\left(\mathrm{BP}_{1 \mathrm{l}}\right)$ and the fertility status index (FS), respectively (Table 4).

\section{Discussion}

In Group II, herd fertility results for a period of 15 months were related to mean phosphorus levels from one single screening of the herds during the indoor winter season. The results obtained in Group I indicate that the mean phosphorus levels are fairly stable throughout the year, especially during the indoor winter season (Fig. 1). A majority of the inseminations in Group II were performed during the indoor season (79\%). This indicates that a single screening of the herds suffices to reveal the true phosphorus status during the main breeding period, as also suggested by Hewett (1974).

The samples in Group I were collected irrespective of the time of the day. Levels of inorganic phosphorus are to some extent related to the carbohydrate metabolism. During increased carbohydrate utilization, levels tend to decrease, and during fasting, an 
Table 3. Level of significance and percentage of total variation for the effects of each factor and model used. The table comprises observations on 262 animals which conceived after calving (Group I).

\begin{tabular}{|c|c|c|c|c|c|}
\hline \multirow{3}{*}{$\begin{array}{l}\text { Fertility } \\
\text { criterion') }\end{array}$} & \multicolumn{4}{|c|}{ Level of significance ${ }^{2)}$ and percentage of total variation } & \multirow[b]{3}{*}{ Model } \\
\hline & \multicolumn{4}{|c|}{ Partial effects ${ }^{3)}$} & \\
\hline & Herd & Calving month & Lactation no. & Phosphorus level & \\
\hline CFII) & $17.2^{* * *}$ & $8.5^{*}$ & n.s. & n.s. & $30.3^{* * *}$ \\
\hline $\mathrm{CCL}$ & n.s. & $9.1^{*}$ & n.s. & $2.3^{*}$ & $21.4^{*}$ \\
\hline $\mathrm{BP}_{1}$ & n.s. & $8.4^{*}$ & n.s. & n.s. & $21.3^{*}$ \\
\hline NIC & $10.6^{*}$ & n.s. & n.s. & $1.9^{*}$ & $23.4^{* *}$ \\
\hline
\end{tabular}

1) $\mathrm{CFI}_{1}=$ Number of days from calving to first insemination

$\mathrm{CC}=$ Number of days from calving to conception

$\mathrm{BP}_{1} \quad=$ Length of the breeding period $\left(\mathrm{BP}_{1}=\mathrm{CC}-\mathrm{CFI}_{1}\right)$

NIC = Number of inseminations per conception

2) Level of significance:

${ }^{*} \quad=\mathrm{p}<0.05,{ }^{* *}=\mathrm{p}<0.01,{ }^{* * *}=\mathrm{p}<0.001, \mathrm{n} . \mathrm{s} .=$ not significant

3) (Variable sum of squares type III/total sum of squares) $\times 100$; by SAS (1982): PROC GLM

Table 4. Level of significance and percentage of total variation for independent variables (kg concentrates, yield, phosphorus level) and the model used. Observations on 47 herds were included (Group II).

\begin{tabular}{lcccc}
\hline \multirow{2}{*}{$\begin{array}{l}\text { Fertility } \\
\text { criterion }\end{array}$} & \multicolumn{3}{c}{ Level of significance ${ }^{2)}$ and percentage of total variation } \\
\cline { 2 - 4 } & \multicolumn{3}{c}{ Partial effects ${ }^{3)}$} \\
\cline { 2 - 4 } & Kg concentrates at & Yield at & Phosphorus & Model \\
\hline $\mathrm{CFI}_{\mathrm{II}}$ & $16.3^{* *}$ & 1st insemination & level & $21.2^{*}$ \\
$\mathrm{CLI}$ & $7.1^{*}$ & n.s. & n.s. & $27.7^{* *}$ \\
$\mathrm{BP}$ & n.s. & n.s. & $18.0^{* * *}$ & $18.2^{*}$ \\
FS & n.s. & n.s. & $15.2^{* *}$ & $19.6^{* *}$ \\
\hline
\end{tabular}

1) $\mathrm{CFI}_{\mathrm{II}}=$ Average number of days from calving to first insemination

$\mathrm{CLI}=$ Average number of days form calving to last insemination

$\mathrm{BP}_{\mathrm{II}}=$ Length of the breeding period $\left(\mathrm{BP}_{\mathrm{II}}=\mathrm{CLI}-\mathrm{CFI}_{\mathrm{II}}\right)$

NIA $=$ Average number of inseminations per animal inseminated

NR60 = Non return rate 60 days after insemination

FS $\quad=$ Fertility status index

2) Level of significance:

${ }^{*}=\mathrm{p}<0.05,{ }^{* *}=\mathrm{p}<0.01,{ }^{* * *}=\mathrm{p}<0.001$, n.s. $=$ not significant

3) (Variable sum og squares type III/total sum of squares) $\times 100$; by SAS (1982): PROC GLM.

increase is usually observed (Simesen 1980). The practical implication of this is, however, uncertain. The results obtained in Group I indicate some variation during the day (Fig. 2 ). This variation is probably only slight and of minor practical importance, especially 
when mean values of several samples collected at different times of the day were used to study the relationship between phosphorus levels and fertility (Group I).

The overall mean phosphorus levels in both materials (Table 1) were within normal ranges (Simesen 1980), though levels were considerably higher, and the variation among herds greater, in Group II than in Group I. The fact that the herds in Group II were recruited from a larger geographical area could explain some of the variation observed. Also, the overall means of the herds were calculated differently for the 2 groups.

The higher levels observed in Group II could to some extent have been a result of sample treatment. Samples from Group II were stored for at least $24 \mathrm{~h}$ before separation of the serum, while samples from Group I were separated immediately. A certain leakage of inorganic phosphorus from the erythrocytes to the serum is likely to occur during storage (Bogin et al. 1982). The magnitude of this leakage may be of importance when comparing the 2 groups, though probably not within the groups (Refsdal 1983, unpublished data).

Although the variance contribution from phosphorus levels on the variation of different fertility criteria was very low in Group I (Table 3), increasing levels of phosphorus were associated with decreased fertility in both groups. This agrees with results obtained by Reisshauer (1971) who reported a marked negative correlation between serum inorganic phosphorus and fertility. In later studies, Hewett (1974) and Lotthammer (1974) came to the same conclusion.

Bogin et al. (1982) reported that the difference between inoganic phosphorus in serum and whole blood $(\delta \mathrm{Pi})$ was significantly related to fertility while serum phosphorus was not. The authors do not give any reasonable explanation for this phenomenon, but sug- gest that $\delta \mathrm{Pi}$ is more sensitive to metabolic changes than is serum inorganic phosphorus. In recent years, several authors have reported the absence of a relationship between phosphorus levels and fertility (Parker \& Blowey 1976, Noller et al. 1977, Carstairs et al. 1980, Larsson et al. 1980).

When compared to normal ranges suggested by Rogers et al. (1986), the mean phosphorus values obtained in the present study, especially in Group I, were in the lower range of normal variation (lower limit $=1.35$ $\mathrm{mmol} / \mathrm{l}$ plasma). The values obtained in Group II were comparable with the values obtained by Parker \& Blowey (1976) (overall mean $=1.75 \mathrm{mmol} / 1$ plasma $),$ Reisshauer 1971 (overall mean $=1.83 \mathrm{mmol} / 1$ serum $)$, Hewett 1974 (overall mean $=1.84 \mathrm{mmol} / \mathrm{l}$ plasma) and others.

The present results are not necessarily in conflict with reports which claim that low dietary phosphorus intake and serum phosphorus values are associated with reduced fertility (Svanberg \& Sandstedt 1944, Hignett \& Hignett 1951 and 1952, Morrow 1969, Cates \& Christensen 1983) since the amounts of phosphorus supplied in the cited studies were probably lower than those in the present investigation. Morrow (1969) reported mean serum phosphorus levels as low as 1.26 $\mathrm{mmol} / \mathrm{l}$ in a phosphorus deficient group. The other studies involved were feeding experiments, and no blood samples were collected.

In conclusion, the results of this study indicate that a negative relationship may exist between serum or plasma levels of inorganic phosphorus and fertility in Norwegian dairy cows. The overall mean phosphorus levels were considered normal in both groups, although herds with reproductive problems (Group II) had considerably higher herd mean levels than herds with normal reproductive results (Group I). 
Although the results showed a negative relationship between phosphorus levels and fertility, one should keep in mind that phosphorus only explained a small part of the total variation of the reproductive parameters studied. The value of phosphorus determination as an aid in the study of reproductive disorders therefore seems limited.

\section{Acknowledgements}

The authors wish to thank S. R. Eriksen, K. Sørensen, and B. Johansson for excellent analytical and technical assistance.

\section{References}

Bogin E, Avidar Y, Davidson M, Gordin S, Israeli $B$ - $A$ : Effect of nutrition on fertility and blood composition in the milk cow. J. Dairy Res. 1982, 49, 13-23.

Carstairs JA, Morrow DA, Emery RS: Postpartum reproductive function of dairy cows as influenced by energy and phosphorus status. J. Anim. Sci. 1980, 51, 1122-1130.

Cates $W F, \&$ Christensen DA: The effect of nutrition on conception rate in beef cows at Cumberland House, Saskatchewan. Canad. vet. J. 1983, 24, 145-147.

Eckles $C H$, Palmer LS, Gullickson TW, Fitch CP, Boyd WL, Bishop L, Nelson JW: Effects of uncomplicated phosphorus deficiency on oestrus cycle, reproduction and composition of tissues of mature dairy cows. Cornell vet. 1935, 25, 22-43.

Hewett $C$ : The relationship between level of fertility and variations in the blood profile. In: On the causes and effects of variations in the blood profile of Swedish dairy cattle. Thesis, Stockholm 1974, 126-136.

Hignett SL, Hignett PG: The influence of nutrition on reproductive efficiency in cattle I. The effect of calcium and phosphorus intake on fertility of cows and hiefers. Vet. Rec. 1951, 63, 603-609.

Hignett $S$, Hignett PG: The influence of nutrition on reproductive efficiency in cattle II. The effect of the phosphorus intake on ovarian activity and fertility of heifers. Vet. Rec. 1952, 64, 203-206.

Larsson LL, Marbruck HS, Lowry SK: Relationship between early postpartum blood composition and reproductive performance in dairy cattle. $\mathrm{J}$. Dairy. Sci. 1980, 63, 283-289.
Lotthammer $\mathrm{K}-\mathrm{H}$ : Haufige Futterungsfehler als Ursache der Herden Sterilität. (Feeding failure as a cause of infertility in dairy herds). Der praktische Tierarzt 1974, 38-42.

Lotthammer $K$ - $H$ : Umweltbedingte Fruchtbarkeitsstörungen. (Environmental causes of infertility). In: E. Grunert \& M. Berchthold (ed): Fertilitätsstörungen beim weiblichem Rind. Paul Parey, Berlin 1982, 390-432.

Morrow DA: Phosphorus deficiency and infertility of dairy heifers. J. Amer. vet. med. Ass. 1969, 154, 761-768.

Noller CH, Castro AG, Wheeler WE, Hill DJ, Moeller $N J$ : Effect of phosphorus supplementation on growth rate, blood minerals, and conception rate of dairy heifers. J. Dairy Sci. 1977, 60, 19321940.

Parker BNJ, Blowey $R W$ : Investigation into the relationship of selected blood components to nutrition and fertility of the dairy cow under commercial farm conditions. Vet. Rec. 1976, 98, 394404.

Reisshauer K: Klinisch-Chemische Untersuchung zur Problematik der Fruchtbarkeitsstörungen bei Rinden. (Clinical-chemical investigations in the diagnosis of reproductive disorders in cattle). Dtsch. tierärztl. Wschr. 1971, 78, 512-516.

Rogers PAM, Power EP, Poole DBR: The phosphorus status of cattle blood in the Munster area. Irish vet. J. 1986, 40, 176-182.

SAS Institute Inc.: SAS User's guide: Statistics. SAS Institute Inc., Cary N.C. 1985.

Simesen MG: Calcium, phosphorus and magnesium metabolism. In: J. J. Kaneko (ed): Clinical Biochemistry of Domestic Animals. Academic Press, New York 1980, 575-648.

Svanberg $O$, Sandstedt $H$ : Om alimentära fertilitetsrubbningar hos nötkreatur, med särskild hänsyn til fosfatfaktorns betydelse. (On alimentary causes of disturbances of fertility in cattle, with special regard to the importance of the phosphate factor.) Svensk Vet.-Tidn. 1944, 384-509.

Theiler von A: Das Phosphordefizit und die Unfruchtbarkeit des Rindes. (Phosphorus deficiency and infertility in cattle). Schweiz. Arch. Tierheilk. 1933, 75, 47-66.

\section{Sammendrag}

Fruktbarhetsresultater hos ku relatert til fosforniva. Nivåene av uorganisk fosfor ble relatert til fruktbar- 
hetsresultater i to grupper. Gruppe I omfattet 305 kyr fra 17 besetninger med normale fruktbarhetsresultater. Besetningene ble besøkt hver andre til fjerde uke, og det ble tatt blodprøve fra kyr fra 4 uker før forventet kalving til konstatert drektighet.

Gjennomsnittlig fosfornivå i plasma for prøver samlet i perioden 0-90 dager etter kalving hos kyr som ble drektige $(n=262)$, ble relatert til fruktbarhetsresultatene hos enkeltkyr. Gruppe II omfattet 47 besetninger med fruktbarhetsproblemer. Det ble tatt blodprøver i besetningene en gang $i$ løpet av innefôringsperioden. Fruktbarhetsresultatene for besetningene ble registrert i en periode fra 6 mảneder før til 9 måneder etter at blodprøver ble tatt. Gjennomsnittlig fosfornivå for besetningene var $1.51 \pm 0.08$ $\mathrm{mmol} / \mathrm{l}$ plasma ( $\pm \mathrm{SD}$ ) (Gruppe I) og $1.77 \pm 0.16$ $\mathrm{mmol} / \mathrm{l}$ serum $( \pm \mathrm{SD})$ (Gruppe II). Det var en tendens til negativ sammenheng mellom fruktbarhet og fosfornivå i Gruppe I. I Gruppe II var det signifikante korrelasjoner mellom FS-tall, gjennomsnittlig avstand fra kalving til siste inseminasjon og fosfornivå (henholdsvis $\mathrm{r}_{\mathrm{s}}=-0.32 \mathrm{p}<0.05$ og $\mathrm{r}_{\mathrm{s}}=0.31 \mathrm{p}$ $<0.05$ ).

Det blir konkludert med at gjennomsnittsnivåene for fosfor $i$ besetningene i begge grupper var innenfor det normale variasjonsområdet. Selv om det var tendens $i$ begge grupper til en negativ sammenheng mellom fosfornivå og fruktbarhet, var det bare en liten del av den totale variasjon som kunne forklares med fosfornivå.

(Received January 22, 1988).

Reprints may be requested from: Erik Ropstad, Norwegian College of Veterinary Medicine P. O. Box 8146, Dep., N-0033 Oslo 1, Norway. 